\begin{tabular}{|l|l|l||}
\hline \multicolumn{2}{|c|}{ PublisherInfo } \\
\hline \hline PublisherName & $:$ & BioMed Central \\
\hline \hline PublisherLocation & $:$ & London \\
\hline \hline PublisherImprintName & $:$ & BioMed Central \\
\hline \hline
\end{tabular}

\title{
Who has finished what?
}

\begin{tabular}{||l|l|l||}
\hline \multicolumn{2}{|c||}{ ArticleInfo } \\
\hline \hline ArticleID & $:$ & 3710 \\
\hline \hline ArticleDOI & $:$ & $10.1186 /$ gb-spotlight-20000627-02 \\
\hline \hline ArticleCitationID & $:$ & spotlight-20000627-02 \\
\hline \hline ArticleSequenceNumber & $:$ & 147 \\
\hline \hline ArticleCategory & $:$ & Research news \\
\hline \hline ArticleFirstPage & $:$ & 1 \\
\hline \hline ArticleLastPage & $:$ & 2 \\
\hline \hline & & \\
\hline ArticleHistory & $:$ & RegistrationDate : 2000-06-27 \\
\hline \hline ArticleCopyright & $:$ & OnlineDate $\quad: 2000-06-27$ \\
\hline \hline ArticleGrants & $:$ & \\
\hline \hline ArticleContext & $:$ & 130591111 Central Ltd2000 \\
\hline \hline
\end{tabular}


The man from CNN was puzzled. Dr Jane Rogers, project manager of human sequencing at the Sanger Centre, the UK's human genome laboratory, had just told the eager press and TV at a news conference at the Wellcome Trust, London, this morning (26 June) that the Human Genome Project had now covered $97 \%$ of the genome.

But only $87 \%$ was sequenced. And only $24 \%$ had reached the "gold standard" of $99.99 \%$ accuracy. And two or three more years' work will be needed to fill gaps in the 28000 clones and reach the desired overall accuracy.

"So why didn't you wait until you'd finished?" asked the TV man.

The somewhat lame answer was that "we always said there'd be a draft by 2000". So said Michael Dexter, Director of the Wellcome Trust- which has spent 210 million pounds on the UK effort amounting to roughly one-third of the human genome - through creating and funding the Sanger Centre, near Cambridge. And "we needed to start a debate about what this work means" Dexter said.

However it is clear there is no particular scientific significance in this moment in the human genome programme (HGP) - except that a lot of good work has been done, and it would be nice to give the boys and girls a pat on the back.

The real fact of the matter is that the HGP had found itself in a race with Craig Venter, the idiosyncratic Director of Celera Corporation in Rockville, Maryland, who said he was about to publish a draft of the genome based on a whole-genome shotgun (the HGP works more slowly, with smaller pieces at a time). And since Venter is in the business of patents and licensing, the public HGP wanted to be in on the act to press its case for freedom of access to the genome sequence.

President Bill Clinton of the USA and Prime Minister Tony Blair of the UK have also been involved, issuing a joint statement on 16 March which said that "to realize the full promise of this research, raw fundamental data on the human genome, including the human DNA sequence and its variations, should be made freely available to scientists everywhere". Celera's shares took a dive.

Then a month ago, Francis Collins, the international project manager of the HGP in the USA, got together with Venter to see if some accommodation could be reached between public and private ventures.

The result is that today Blair and Clinton were together with Craig Venter and Francis Collins at the White House, announcing a degree of accommodation over freedom of access. Venter opened by talking of the "different approaches - and" [interestingly] "in some cases results" of the two projects. He claimed $99 \%$ of the genome (compare the HGP's 97\%). Francis looked forward to a time not far away when the Celera and HGP sequences could be publicly compared, and publicly thanked Venter for making an agreement to this effect with the HGP.

According the White House, the HGP "will continue its long-standing practice of making all of its sequencing data available to public and privately funded researchers worldwide at no cost. Celera 
Genomics, which makes its sequencing data available by subscription, will also make its version of the consensus human genome sequence available to non-subscribers upon publication".

What Celera itself says in its own press statementtoday is this: "Celera now begins the phase known as annotation whereby the located genes are further analyzed to start the process of understanding their particular function. Celera is on target to submit a paper for publication on the consensus genome later this year...

"Upon publication, the data will be freely available to academic researchers worldwide via Celera's web site. Celera's academic, pharmaceutical, and biotechnology subscribers have immediate access to the database and sophisticated bioinformatics tools for analysis of the genome. Other database companies will not be able to redistribute Celera's data."

\section{References}

1. Wellcome Trust press release., [http://www.sanger.ac.uk/HGP/draft2000/]

2. The White House statement., [http:/www.whitehouse.gov/WH/New/html/20000626.html]

3. The Celera press release., [http://www.celera.com/corporate/about/press_releases/ celera062600_1.html] 